\title{
Epidermal Growth Factor Enhances Invasive Activity of BeWo Choriocarcinoma Cells by Inducing $\alpha 2$ Integrin Expression
}

\author{
YUKI NAKATSUJI, YUKIHIRO NISHIO, NAOYUKI TANI*, KAZUSHIGE ADACHI, MASAHIDE OHMICHI**, \\ KOJI HISAMOTO, KEN-ICHIROU MORISHIGE, HIROHISA KURACHI**, KEIICHI TASAKA, YUJI MURATA \\ AND NARIAKI MATSUURA*
}

Department of Obstetrics and Gynecology, Faculty of Medicine, Osaka University, Suita, Osaka 565-0871, Japan *School of Allied Health Sciences, Faculty of Medicine, Osaka University, Suita, Osaka 565-0871, Japan

**Department of Obstetrics and Gynecology, School of Medicine, Yamagata University, Yamagata 990-9585, Japan

\begin{abstract}
The trophoblast, an important component of the mammalian placenta, has several essential biological roles in the maintenance of pregnancy. First, trophoblast cells must attach to the uterine endometrium, and then they must invade to a depth at which the vascular network exists. Here, we investigated the effects of epidermal growth factor (EGF) on $\alpha 2$ integrin expression, adhesiveness to collagen, and invasive activity using human BeWo choriocarcinoma cells. EGF induced the expression of $\alpha 2$ integrin mRNA and protein, as shown by Northern blotting, Western blotting, and flow cytometry. Human chorionic gonadotropin (hCG) secretion was enhanced by the addition of EGF, which suggests that the BeWo cells functionally differentiated similarly to normal trophoblasts. EGF also dose-dependently stimulated the invasiveness of BeWo cells. Antibody against $\alpha 2$ integrin inhibited this effect, suggesting that it may be mediated by an increase of cell surface integrin. EGF had no effect on the adhesiveness of BeWo cells to collagen, whereas it stimulated the chemokinetic activity in a dose-dependent manner. The increase of chemokinetic activity was suppressed by antibody against $\alpha 2$ integrin. These results suggest that EGF may induce $\alpha 2$ integrin expression in trophoblast cells, thereby enhancing their invasiveness into the endometrium via an increase of their chemokinetic activity.
\end{abstract}

Key words: Trophoblast, Epidermal growth factor, $\alpha 2$ integrin, Invasion

(Endocrine Journal 50: 703-714, 2003)

FORMATION of the maternal-fetal interface, a consequence of trophoblast differentiation, is essential for the maintenance of pregnancy. During human placental development, trophoblast cells establish a firm adhesive base on the uterine wall, invade the superficial uterine vasculature and migrate along the endometrium $[1,2]$. The invasion is initiated as soon as implantation occurs, and the invasive activity is greatly accelerated when the columnar epithelium (chorionic villi) is formed $[3,4]$. The final destination of the trophoblast invasion is the uterine spiral arteries,

Received: December 3, 2002

Accepted: July 22, 2003

Correspondence to: Dr. Yukihiro NISHIO, Department of Obstetrics and Gynecology, Faculty of Medicine, Osaka University, Suita, Osaka 565-0871, Japan where the cells obtain an oxygen supply [5].

The interactions of trophoblast cells with various extracellular matrix (ECM) proteins play important roles in the maintenance of the adhesion and invasion into the uterus. Integrins, the major cell surface receptors for ECM proteins, are membrane glycoproteins that anchor extracellular adhesion proteins to cytoskeletal components $[6,7]$. Integrins are heterodimers composed of different $\alpha$ and $\beta$ subunits and include cell surface receptors for fibronectin, collagen, laminin and vitronectin $[8,9]$. Many reports have shown that cell surface integrins are expressed in trophoblast cells [10-12]. For example, cytotrophoblast (CTB) and villi stem cells express $\alpha 6 \beta 4$ integrin. As differentiation proceeds, the CTB upregulates the expression of $\alpha 5 \beta 1$ integrin in cell columns and of $\alpha 1 \beta 1$ integrin in the uterine wall, while it downregulates the expression of 
$\alpha 6 \beta 4$ integrin. The switch from $\alpha 6 \beta 4$ to $\alpha 5 \beta 1$ integrin appears to be essential to the differentiation of the CTB [13].

In general, $\alpha 2 \beta 1$ integrin is a major receptor for collagen, and its expression is associated with reorganization of connective tissue in fibroblasts [14]. Recently, it was reported that $\alpha 2 \beta 1$ integrin is transiently expressed in the CTB during implantation [15]. These facts raise the possibility that cytokines or growth factors secreted around the maternal-fetal interface play a role in regulating the integrin expression profiles. We focused on epidermal growth factor (EGF) among such factors, because there have been several reports that EGF is produced in the uterus during the peri-implantation period [16-18]. In addition, the EGF receptor is expressed on the trophoectoderm [19] and EGF promotes mouse trophoblast outgrowth [20] and blastocoel expansion [21] as well as human cytotrophoblast invasion [22].

In this study, we investigated the effect of EGF on the integrin expression profile and the invasive activity of human BeWo choriocarcinoma cells. BeWo cells have several characteristics of the normal trophoblast, including the secretion of human chorionic gonadotropin (hCG) and the expression of high affinity receptors to EGF [23], and provide a system for elucidating biological mechanisms in trophoblast cells. We show here that EGF induces the invasiveness of BeWo cells via an increase of their chemokinetic activity and that the expression of $\alpha 2$ integrin is involved in the induction.

\section{Materials and Methods}

\section{Antibodies}

The anti-human $\alpha 2$ integrin antibodies used in this study were as follows: for immunoblot experiments, rabbit polyclonal antibody (Cat \#AB1936, Chemicon) was used; for invasion assays and Boyden chamber assays, mouse monoclonal antibody P1E6 (Cat \#MAB1950Z, Chemicon) was used. Anti-GSK3 $\alpha$ antibody (H-75) was purchased from Santa Cruz Biotechnology Inc.

The antibodies used in flow cytometry analysis, invasion assays, adhesion assays, and Boyden chamber assays were as follows: anti- $\alpha 1$ : HP2B6, $\alpha 2$ : P1E6, $\alpha 3$ : P1B5, $\alpha 4$ : SG/73, $\alpha 5: \mathrm{KH} / 72, \alpha 6: \mathrm{GoH} 3, \beta 1: \mathrm{SG} /$
19, respectively. SG73, KH/72, and SG/19 were kind gifts from Dr. Kensuke Miyake (Institute of Medical Science, University of Tokyo). GoH3 and HP2B6 were purchased from Chemicon.

\section{Cell culture}

The BeWo human choriocarcinoma cell line was maintained in HAM's F-12K (Sigma) supplemented with 15\% FBS (JRH Biosciences Nichirei Co.), $100 \mathrm{IU} / \mathrm{ml}$ penicillin, and $100 \mu \mathrm{g} / \mathrm{ml}$ streptomycin. The cells were maintained as monolayers in $250-\mathrm{ml}$ flasks (Falcon Becton Dickinson) at $37^{\circ} \mathrm{C}$ in a humidified atmosphere of $5 \% \mathrm{CO}_{2}$ in air. Human recombinant EGF (236-EG), LIF (250-L), and TGF- $\beta$ (100B) were purchased from R \& D Systems, Inc.

\section{Determination of $h C G$ secretion profile}

The BeWo cells $\left(5 \times 10^{5}\right)$ were plated in 24-well plates in $1 \mathrm{ml} /$ well of HAM's F-12K supplemented with $15 \%$ FBS. The next day, the medium was replaced with HAM's F-12K containing 1\% FBS with or without $10 \mathrm{nM}$ EGF. After $12 \mathrm{~h}, 24 \mathrm{~h}$, or $48 \mathrm{~h}$, the culture media were collected and the concentration of $\mathrm{hCG}$ in the culture media was measured using an enzyme immunoassay analyzer (Nissui Seiyaku Corporation). To normalize for the cell growth effects, the number of cells was counted by staining the cells with Trypan Blue and examining them under a microscope at each time indicated.

\section{Flow cytometry}

The BeWo cells were treated with HAM's F-12K medium containing $1 \%$ FBS with or without $10 \mathrm{nM}$ EGF for $24 \mathrm{~h}$. Then the cells were trypsinized and resuspended in suspension medium (MEM with $0.03 \%$ $\mathrm{NaN}_{3}, 1 \%$ FBS). The suspended cells were transferred to a 96-well cell culture plate at a density of $2 \times 10^{5}$ cells/well and incubated for $30 \mathrm{~min}$ at $4^{\circ} \mathrm{C}$ with $10 \mu \mathrm{l}$ of anti- $\alpha 2$ integrin mouse monoclonal antibody (100 $\mu \mathrm{g} / \mathrm{ml})$. The cells were washed twice with the suspension medium and incubated with $1.5 \mu \mathrm{l}$ of FITCconjugated rabbit anti-mouse immunoglobulin for 30 $\min$ at $4^{\circ} \mathrm{C}$. The cells were then washed twice and resuspended in the suspension medium. Cell surface integrin expression was analyzed using a FACScan flow cytometer (Becton Dickinson, San Jose, CA). 


\section{RNA extraction}

Total cellular RNA was extracted from BeWo cells cultured in HAM's F-12K medium supplemented with $1 \%$ FBS for $24 \mathrm{~h}$ and harvested immediately ( 0 time) or further cultured for $3,6,12$, or $24 \mathrm{~h}$ in the same medium in the presence of $10 \mathrm{nM}$ EGF and then harvested. Total RNA was extracted using Trizol Reagent (Gibco BRL) following the manufacturer's instructions. The concentration of RNA was determined by measuring the absorbance at $260 \mathrm{~nm}$.

\section{Northern blotting}

Total RNA $(10 \mu \mathrm{g})$ was separated by formaldehydeagarose gel electrophoresis, transferred to Nytran membranes (Hybond-N, Amersham-Pharmacia) and analyzed by Northern blot hybridization using a ${ }^{32} \mathrm{P}$ labeled cDNA probe. Loading of equal amounts of RNA in each lane was verified by staining $28 \mathrm{~S}$ and $18 \mathrm{~S}$ ribosomal RNAs on the membranes with methylene blue and assessment by visual inspection. The radiolabeled probes for human $\alpha 2$ integrin or human GAPDH were synthesized by random priming of full-length cDNA using a Megaprime labeling kit (Amersham-Pharmacia) according to standard methods. The final post-hybridization washing consisted of two rinses in $2 \times \mathrm{SSC}$ at $42^{\circ} \mathrm{C}$ for $10 \mathrm{~min}$ each, followed by a rinse in $0.5 \times \mathrm{SSC}, 0.1 \% \mathrm{SDS}$ at $65^{\circ} \mathrm{C}$ for $10 \mathrm{~min}$. The radioactivity of each band was quantified using a BAS2000 imaging system (Fuji Film, Tokyo, JAPAN).

\section{Western blotting}

The BeWo cells were washed twice with phosphatebuffered saline and lysed in ice-cold buffer consisting of $50 \mathrm{mM}$ HEPES, $\mathrm{pH} 7.5,150 \mathrm{mM} \mathrm{NaCl}, 10 \%$ glycerol, $1 \%$ Triton X-100, $1.5 \mathrm{mM} \mathrm{MgCl}_{2}, 1 \mathrm{mM}$ EDTA, $2.5 \mathrm{mM}$ sodium pyrophosphate, $1 \mathrm{mM}$ sodium orthovanadate, $10 \mu \mathrm{g} / \mathrm{ml}$ aprotinin, $10 \mu \mathrm{g} / \mathrm{ml}$ leupeptin, and $1 \mathrm{mM}$ PMSF. The extracts were centrifuged to remove cellular debris, and the protein content of the supernatants was determined using the Bio-Rad protein assay reagent (Bio-Rad). The extracts $(150 \mu \mathrm{g}$ of protein) were then subjected to $10 \%$ SDS-PAGE and transferred to nitrocellulose membranes. After a blocking reaction $(5 \%$ nonfat dry milk in Tris-buffered saline, $\mathrm{pH} 7.4,0.05 \%$ Tween-20) for $1 \mathrm{~h}$, membranes were incubated in the blocking buffer supplemented with anti- $\alpha 2$ integrin or anti-GSK-3 $\alpha$ rabbit polyclonal antibody overnight at $4{ }^{\circ} \mathrm{C}$. After incubation with horseradish peroxidase-linked anti-rabbit $\mathrm{IgG}$, the membranes were developed by using the ECL system (Amersham-Pharmacia) according to the manufacturer's instructions. The signal intensity of each band was quantified using a FluorChem 8000 (Alpha Innotech Corporation Inc., San Leandro, CA, USA).

\section{Invasion assay}

BeWo cells $\left(2 \times 10^{5}\right)$ were trypsinized and resuspended in HAM's F-12K medium containing $0.1 \%$ BSA (Sigma). Then the cells were seeded into the upper compartments of transwell chambers containing polycarbonate membranes with $12-\mu \mathrm{m}$-diameter pores, which were placed in the wells of a 12-well tissue culture plate (Corning Costar Corporation) [24, 25]. The upper surface of the membranes was coated with cold Matrigel $(100 \mu \mathrm{g} / \mathrm{ml})$ and the filters were air-dried for $24 \mathrm{~h}$ at room temperature. Prior to use, the upper chambers were rehydrated with $100 \mu \mathrm{l}$ of HAM's F-12K medium for $1 \mathrm{~h}$. The lower chambers were loaded with $1.5 \mathrm{ml}$ of HAM's F-12K medium containing $0.1 \% \mathrm{BSA}$ in the absence or presence of $\mathrm{EGF}$ at the indicated concentrations for $24 \mathrm{~h}$. After 24 $\mathrm{h}$ of culturing, non-invading cells in the upper chambers were removed with a cotton swab. Cells on the underside of the membranes were fixed with $10 \%$ formaldehyde for $30 \mathrm{~min}$ at room temperature, and stained with hematoxylin and eosin. For quantification, the cells invading to the lower surface were counted under a microscope in pre-determined fields at a magnification of $\times 200$. For blocking assays, anti- $\alpha 1$ or $-\alpha 2$ integrin antibody or control mouse IgG1 was added to the medium in the upper chamber at a final concentration of $10 \mu \mathrm{g} / \mathrm{ml}$ immediately after plating the cells.

\section{Cell adhesion assay}

The BeWo cells were treated with HAM's F-12K medium containing $1 \% \mathrm{FBS}$ in the absence or presence of EGF at the indicated concentrations for $24 \mathrm{~h}$. For adhesion assays [26, 27], 96-well tissue culture plates were coated with type IV collagen or fibronectin for $2 \mathrm{~h}$ at $37^{\circ} \mathrm{C}$. Nonspecific binding sites were blocked by preincubation with $3 \% \mathrm{BSA}$ for $1 \mathrm{~h}$ at $37^{\circ} \mathrm{C}$. The blocking buffer was then removed by suctioning. The 
cells were trypsinized and resuspended in HAM's F$12 \mathrm{~K}$ medium containing $0.1 \%$ BSA. The dispersed cells were seeded $\left(2 \times 10^{5}\right.$ cells/ well $)$ in the culture plates and allowed to adhere for $1 \mathrm{~h}$ at $37^{\circ} \mathrm{C}$. Then the medium was removed by suctioning and $0.04 \%$ crystal violet was added to each well. The cells were stained for $10 \mathrm{~min}$ at room temperature and washed three times with PBS, and then $30 \mu \mathrm{l}$ of DMSO was added to each well. After incubation for $10 \mathrm{~min}$ at room temperature, $70 \mu \mathrm{l}$ of double-distilled water was added to each well. The absorbance was measured at $590 \mathrm{~nm}$.

\section{Boyden chamber assay}

Chemotaxis of BeWo cells was quantitated using a modified 48-well Boyden chamber (Neuroprobe, MD) [26-28] and polycarbonate membranes with a pore diameter of $12 \mu \mathrm{m}$ (Neuro Probe Inc., Gaithersburg, MD) coated on both sides with collagen by immersion in a $10 \mu \mathrm{g} / \mathrm{ml}$ collagen solution. The BeWo cells were treated with HAM's F-12K medium containing $1 \%$ FBS in the absence or presence of EGF at the indicated concentrations for $24 \mathrm{~h}$. Then the cells were seeded at a concentration of $1 \times 10^{6} / \mathrm{ml}$ in HAM's F-12K medium containing $0.1 \% \mathrm{BSA}$ in the top wells, and HAM's F-12K medium containing $0.1 \%$ BSA and various concentrations of EGF was placed in the bottom wells. Cells were then allowed to migrate for $3 \mathrm{~h}$ at $37^{\circ} \mathrm{C}$ in a humidified atmosphere of $5 \% \mathrm{CO}_{2}$ in air. Migrating cells on the lower surface of the membranes were fixed with formaldehyde and stained with hematoxylin. For quantitative assessment of migrating cells, the cells in four different fields from each well were counted. Next, blocking assays were performed in the same way, except that the cells were pretreated with anti- $\alpha 1$ or $\alpha 2$ integrin antibody or mouse IgG1 for $1 \mathrm{~h}$ at $4^{\circ} \mathrm{C}$ before they were added to the top wells.

\section{Statistical analysis}

The paired $t$ test was used to assess whether there were significant differences in $\mathrm{hCG}$ secretion between EGF-treated and untreated cells at each time point after EGF treatment. The same test was performed to examine the statistical significance of differences in the invasive activity or chemokinesis activity between the control and EGF-treated cells at each EGF concentration. Two-way ANOVA was used to deter- mine whether there were significant differences in the invasive activity or chemokinesis activity among treatments with different antibodies. $\mathrm{P}<0.05$ was considered statistically significant. The analyses were performed with a statistics software package (Statview 4.02, Abacus Concepts Inc., Berkeley, CA).

\section{Results}

\section{Effect of EGF on functional differentiation of BeWo choriocarcinoma cells}

Previous studies utilizing isolated trophoblast cells as well as several choriocarcinoma cell lines [29, 30] indicated that hCG secretion was increased by addition of EGF in a time-dependent manner. We first examined the responsiveness of BeWo choriocarcinoma cells to EGF by monitoring hCG secretion in order to confirm that the characteristics of the BeWo cells were appropriate for subsequent analysis. Fig. 1 shows a representative hCG secretion profile after $12 \mathrm{~h}, 24 \mathrm{~h}$,

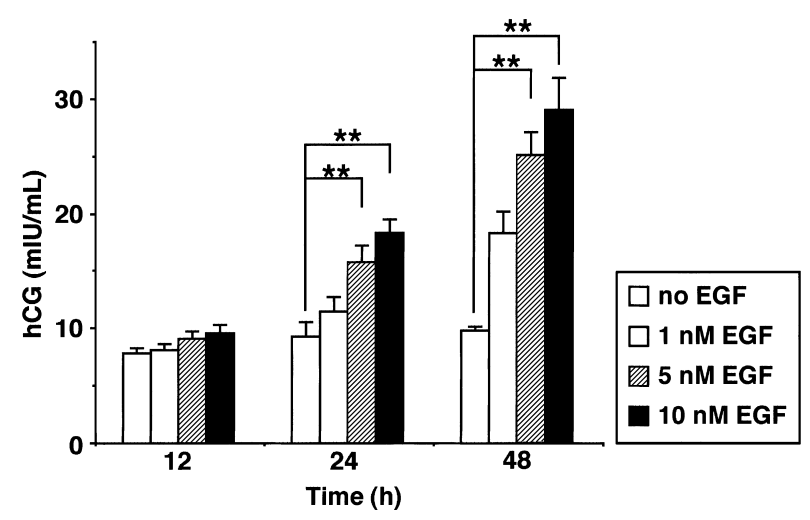

Fig. 1. Effect of EGF on hCG secretion from BeWo choriocarcinoma cells

BeWo choriocarcinoma cells were cultured in HAM's F-12K medium supplemented with $1 \%$ FBS in the absence or presence of different concentrations of EGF for 12,24 , or $48 \mathrm{~h}$. The culture medium was collected and subjected to quantification of the hCG concentration using an automated enzyme immunoassay system. The effect of cell number was taken into account by normalizing the level of hCG relative to the number of cells in each well. Data are shown as the mean \pm S.D. $(\mathrm{n}=4)$. The paired $t$ test was used to assess whether there were significant differences in hCG secretion levels between control and EGF-treated conditions at each treatment time point. Statistically significant differences are indicated by asterisks $(* *, \mathrm{P}<0.01)$. 
and $48 \mathrm{~h}$ in the presence or absence of various concentrations of EGF. The hCG concentration increased with time in a dose-dependent manner when the cells were treated with EGF, whereas the hCG concentration remained unchanged in the absence of EGF. These results show that the BeWo cells we used in the following experiments possess important biological
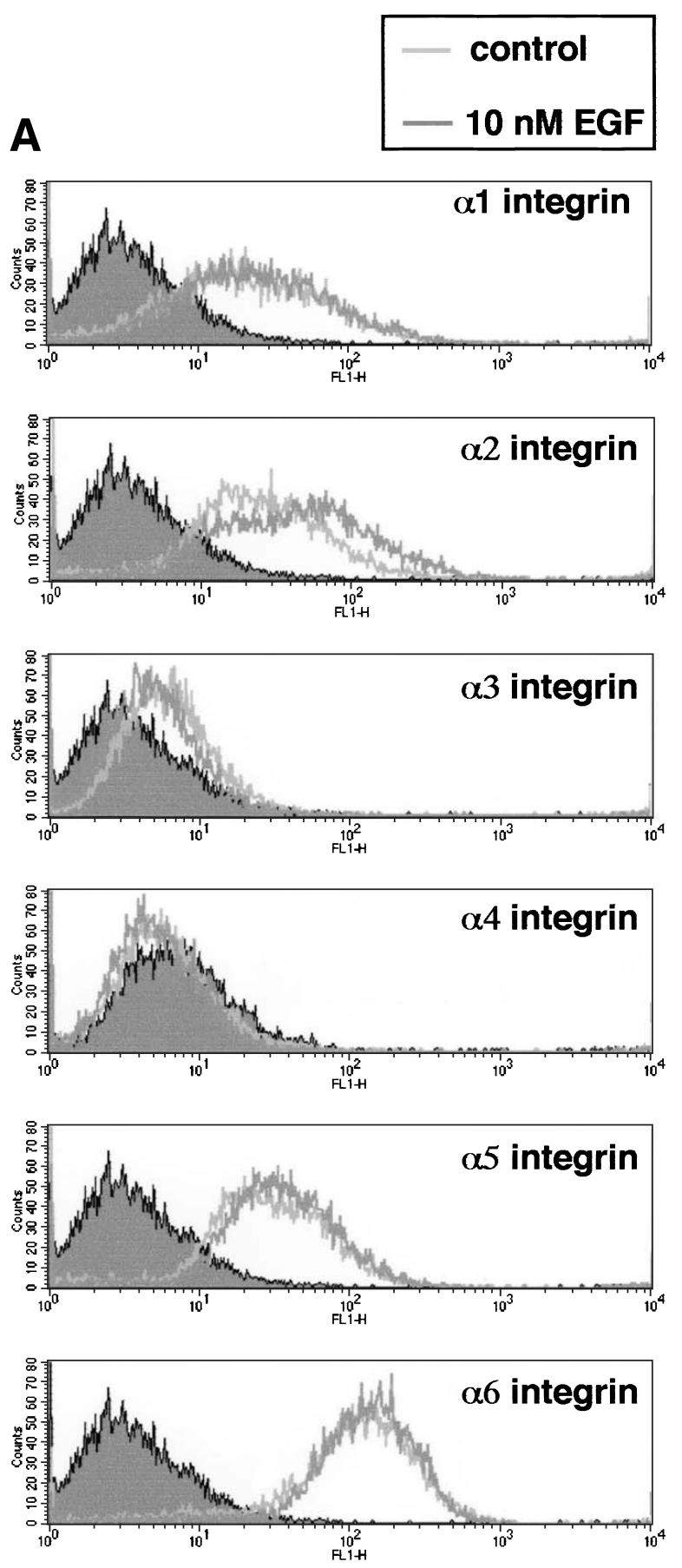

characteristics of CTBs.

Expression of a2 integrin in response to EGF

We next investigated the effects of EGF on the expression of integrins on the surface of BeWo cells. Fig. 2A shows representative flow cytometry analyses
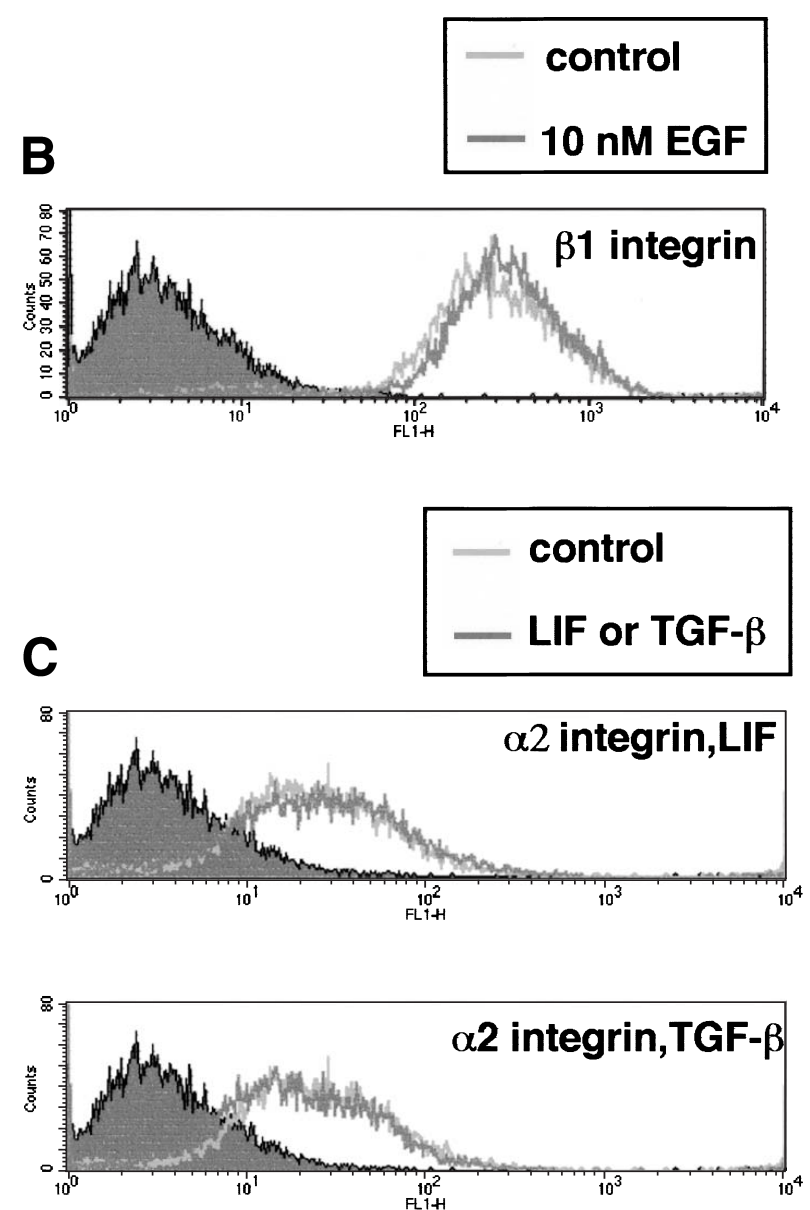

Fig. 2. Effect of EGF on the expression of various integrins on the surface of BeWo cells

BeWo cells were cultured for $24 \mathrm{~h}$ under the same conditions described in the legend for Fig. 1. The cells were stripped from the culture flasks, incubated with mouse anti-integrin antibodies, and then washed extensively with chilled PBS. The washed cells were then incubated with FITC-conjugated anti-mouse IgG antibody and analyzed using a FACScan flow cytometer. The effects of $10 \mathrm{nM}$ EGF on (A) $\alpha 1-\alpha 6$ integrins and (B) $\beta 1$ integrin, and the effect of $0.1 \mathrm{ng} / \mathrm{ml} \mathrm{LIF}$ and $10 \mathrm{ng} / \mathrm{ml}$ TGF- $\beta$ on $\alpha 2$ integrin expression (C) are shown. The ordinate shows cell numbers (Counts), and the abscissa shows the relative fluorescence intensity on an arbitrary scale (FL1-H). All experiments were repeated at least three times with consistent results. 
of cells incubated with or without $10 \mathrm{nM}$ EGF for $24 \mathrm{~h}$. With regard to $\alpha$ integrins, it was demonstrated that several molecules, including $\alpha 1, \alpha 2, \alpha 5$, and $\alpha 6$ integrins, were constitutively expressed, while the expression of $\alpha 3$ and $\alpha 4$ integrins was weak. Treatment of the cells with EGF resulted in enhanced expression of $\alpha 2$ integrin alone. Flow cytometry at various points, including $6 \mathrm{~h}$ and $12 \mathrm{~h}$, after the addition of $10 \mathrm{nM}$ EGF showed that EGF enhanced the expression of $\alpha 2$ integrin at those times, but not as markedly as at $24 \mathrm{~h}$ after the addition of EGF (data not shown). Because $\alpha 2$ integrin forms a heterodimer with $\beta 1$ integrin, we also examined the effect of EGF on $\beta 1$ integrin expression by performing flow cytometry analyses under the same conditions as for $\alpha 2$ integrin. We found that $\beta 1$ integrin was abundantly expressed on BeWo cells. However, EGF had no apparent effect on $\beta 1$ integrin expression (Fig. 2B). To test whether the augmentation of $\alpha 2$ integrin expression occurs with cytokines other than EGF, the cells were also treated with $0.1 \mathrm{ng} / \mathrm{ml}$ of leukemia inhibitory factor (LIF) or $10 \mathrm{ng} / \mathrm{ml}$ transforming growth factor $\beta$ (TGF$\beta$ ), both of which are cytokines known to induce differentiation of trophoblast cells [31, 32]. These two cytokines did not alter the expression profile of $\alpha 2$ integrin (Fig. 2C).

\section{Enhancement of $\alpha 2$ integrin $m R N A$ and protein expression by $E G F$}

To examine the mechanism by which the cell surface $\alpha 2$ integrin protein was induced by EGF, we next investigated the effect of EGF on $\alpha 2$ integrin expression at the level of mRNA expression. For this purpose, we performed Northern blot analysis with total RNA samples prepared from BeWo cells after stimulation with $10 \mathrm{nM}$ EGF. As shown in Fig. 3A, $\alpha 2$ integrin mRNA expression was maximally augmented after $3 \mathrm{~h}$ of EGF treatment (image scanning showed a 8.5 -fold increase compared to the basal level; data not shown). Moreover, a time-course study showed that the amount of $\alpha 2$ integrin mRNA gradually decreased thereafter through $24 \mathrm{~h}$ after stimulation. These results suggest that the expression of $\alpha 2$ integrin is induced by EGF at the level of mRNA expression. Next, we examined the time-course of
A

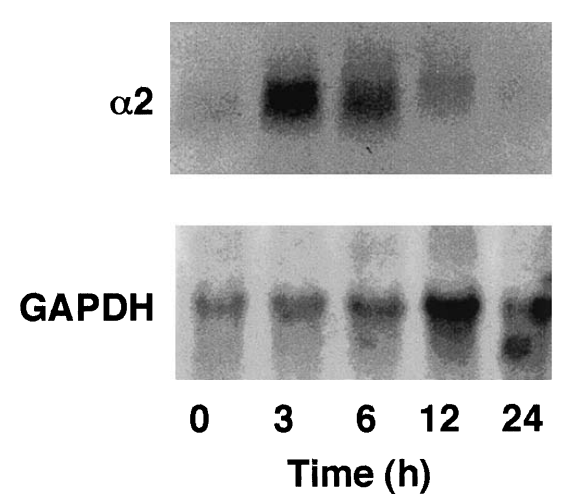

B

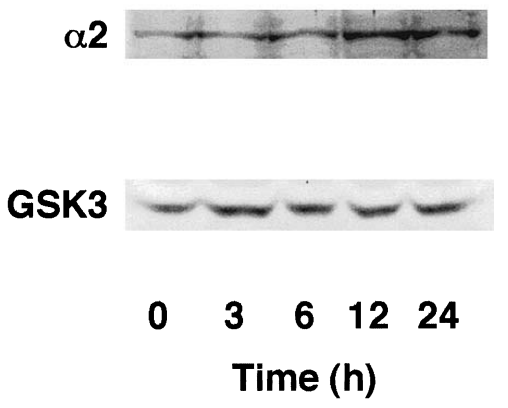

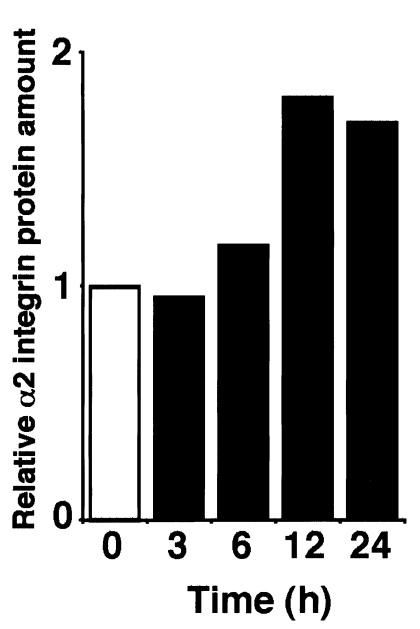

Fig. 3. Induction of $\alpha 2$ integrin mRNA and protein by EGF

A, BeWo cells were cultured for the periods indicated in the panel in the presence of $10 \mathrm{nM}$ EGF under the same culture conditions as described in the legend for Fig. 1. The RNA samples were electrophoresed on a $1.2 \%$ agarose gel and then blotted onto a Nytran membrane. The blot was hybridized with ${ }^{32} \mathrm{P}$-labeled $\alpha 2$ integrin cDNA. The same membrane was rehybridized with ${ }^{32} \mathrm{P}$-labeled GAPDH cDNA and the radioactivity in each band was quantitated as described in Materials and Methods. B, (Left) Total cell lysates from BeWo cells treated under the same conditions as in A were prepared as described in Materials and Methods. Each lysate was subjected to SDS-PAGE and the separated proteins were transferred to a nitrocellulose membrane. Immunoblotting was performed with rabbit anti-human $\alpha 2$-integrin antibody (top) or anti-GSK3 $\alpha$ antibody (bottom) and immunoreactive proteins were visualized using the ECL system (Amersham-Pharmacia). $\alpha 2: \alpha 2$ integrin, GSK3: glycogen synthase kinase 3 alpha. (Right) Densitometric analysis was carried out to quantify $\alpha 2$ integrin protein expression in the absence (white column) or the presence (black columns) of EGF. The density of each $\alpha 2$ integrin band was normalized by the density of the GSK3 protein band in the same lane. 
expression of $\alpha 2$ integrin protein by Western blot analysis. EGF augmented $\alpha 2$ integrin protein expression; however, the induction was observed much later than that of mRNA. The level of $\alpha 2$ integrin protein gradually increased starting $6 \mathrm{~h}$ after the addition of EGF, and it reached a plateau from $12 \mathrm{~h}$ through $24 \mathrm{~h}$, while the amount of GSK-3 $\alpha$ protein remained constant (Fig. 3B).

Involvement of $\alpha 2$ integrin expression in EGF-induced invasive activity of BeWo cells

To assess the biological effects of EGF-induced $\alpha 2$ integrin expression, we examined the invasive activity of BeWo cells in the presence or absence of EGF. Invasion assays showed that treatment with EGF for $24 \mathrm{~h}$ increased the invasive activity of BeWo cells in a dose-dependent manner (Fig. 4A). Because EGF induced $\alpha 2$ integrin expression in the cells, we next examined the effect of antibody against $\alpha 2$ integrin on the invasive activity to address whether $\alpha 2$ integrin is involved in this effect. As shown in Fig. 4B, the invasive activity of the EGF-treated cells was markedly decreased by the addition of the anti- $\alpha 2$ integrin antibody compared to the activity of cells treated with control mouse IgG1 or anti- $\alpha 1$ integrin antibody. These data indicate that $\alpha 2$ integrin plays a major role in the EGF-induced invasive activity of BeWo cells.

\section{Effect of EGF on adhesion of BeWo cells to collagen}

Because the invasion process involves adhesion and chemokinesis of the cells, we investigated the effect of EGF on the adhesion of BeWo cells. Fig. 5 shows the results of adhesion assays using a type IV collagen matrix. EGF had no effect on the adhesion of BeWo cells at a concentration of $1 \mathrm{nM}$ or $10 \mathrm{nM}$. When the matrix was changed to fibronectin, another ligand for $\alpha 2$ integrin, EGF did not alter the adhesion of BeWo cells either under the same experimental conditions (data not shown).

Enhancement of chemokinesis of BeWo cells by EGF via induction of $\alpha 2$ integrin

We next performed Boyden chamber assays to
A

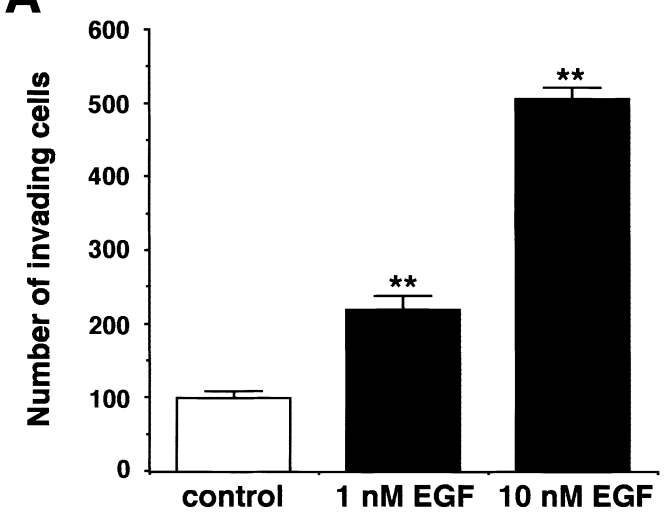

B

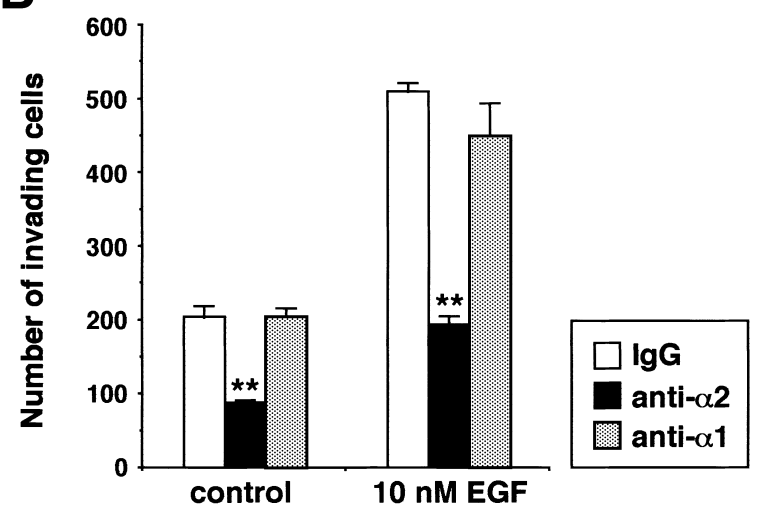

Fig. 4. Effect of EGF on, and involvement of $\alpha 2$ integrin in, the invasive activity of BeWo cells

A, BeWo cells $\left(2 \times 10^{5}\right)$ were pre-incubated in the absence (control) (white column) or presence (black columns) of different concentrations of human EGF for $24 \mathrm{~h}$, collected from the culture flasks and resuspended in HAM's F-12K medium. The cells were then placed in transwell chambers on membranes coated with $100 \mu \mathrm{g} / \mathrm{ml}$ Matrigel. Twelve hours later, the membrane was removed from each chamber and stained with hematoxylin to visualize the cells that had reached the bottom surface of the membrane. The cell numbers are shown on the graph. Regression analysis indicated a significant positive relationship between the EGF concentration and the number of invading cells. The paired $t$ test was used to assess whether there were significant differences in the number of invading cells between the control and each EGF-treated condition. Statistically significant differences are indicated by asterisks $(* *, \mathrm{P}<0.01)$.

$\mathrm{B}$, BeWo cells $\left(2 \times 10^{5}\right)$ were pre-incubated with (right set of columns) or without (control) (left set of columns) $10 \mathrm{nM}$ human EGF for $24 \mathrm{~h}$ in the presence of mouse anti- $\alpha 2$ integrin antibody (black columns), control mouse IgG1 (white columns), or anti- $\alpha 1$ integrin antibody (shaded columns). Results are expressed as the number of invading cells. Data are shown as the mean \pm S.D. $(n=4)$. Two-way ANOVA was used to assess whether there were significant differences in the number of invading cells within the same EGF concentration with different antibody treatments. Statistically significant differences are indicated by asterisks (**, $\mathrm{P}<0.01)$. 


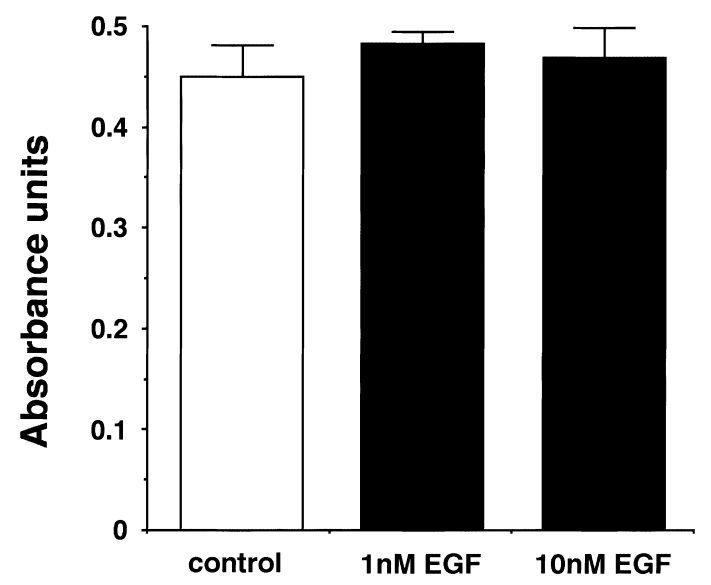

Fig. 5. Effect of EGF on the adhesion of BeWo cells to a collagen matrix

BeWo cells were cultured in the absence (control) (white column) or presence (black columns) of different concentrations of human EGF for $24 \mathrm{~h}$. The cells were trypsinized and resuspended in HAM's F-12K medium. The dispersed cells were seeded $\left(2 \times 10^{5}\right.$ cells/ well $)$ in 96-well collagen-coated tissue culture plates coated with a $10 \mu \mathrm{g} / \mathrm{ml}$ collagen solution. One hour later, the culture medium was removed by aspiration and the cells remaining on the culture plate surface were stained with $0.04 \%$ crystal violet solution and the A595 was measured to quantify the ability to adhere to collagen and is shown on the ordinate (Fluorescence units). Data are shown as the mean \pm S.D. $(n=4)$. quantify the chemokinetic activity of the cells. EGF enhanced the chemokinetic activity of BeWo cells in a dose-dependent manner (Fig. 6A). We also investigated the effect of anti- $\alpha 2$ integrin antibody on the EGF-induced chemokinetic activity. Fig. 6B shows that the chemokinetic activity of BeWo cells was suppressed by the addition of the same antibody that caused inhibition in the invasion assay compared to the chemokinetic activity of cells treated with control mouse IgG1 or anti- $\alpha 1$ integrin antibody. These results indicate that the increase of $\alpha 2$ integrin is involved in the induction of the chemokinetic activity of BeWo cells by EGF.

\section{Discussion}

Integrins provide physical linkage between the cytoskeleton and ECM and they transduce signals initiated by extracellular interactions [33]. The $\alpha$-integrin subunits have diverse amino acid sequences and distinct functions [33]. $\alpha 2$ integrin is expressed on many cell types, including breast, colon, fibroblast and endothelial cells, and forms a heterodimer with $\beta 1$ integrin [34]. In skin and mucosa, $\alpha 2$ integrin is located
A

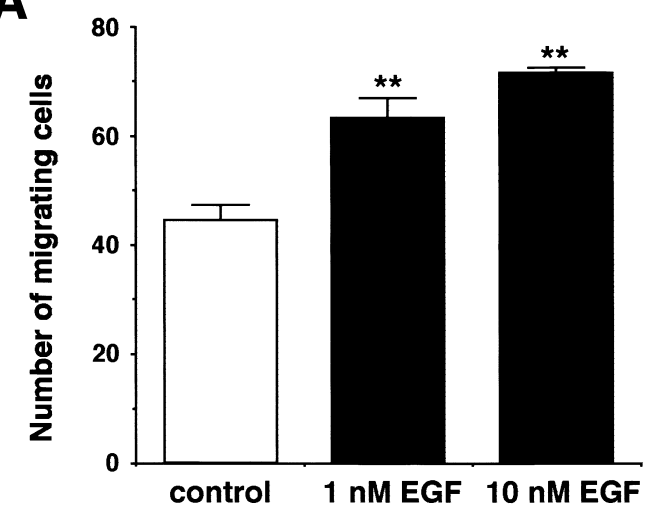

B

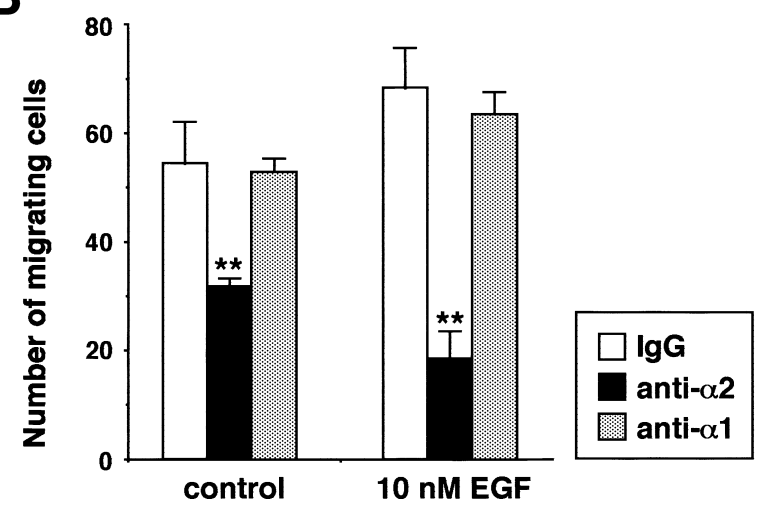

Fig. 6. Effect of EGF on, and the involvement of $\alpha 2$ integrin in, the chemokinetic activity of BeWo cells

A, Nitrocellulose membranes with $12-\mu \mathrm{m}$ pores were coated with $10 \mu \mathrm{g} / \mathrm{ml}$ collagen solution and placed in Boyden chambers. BeWo cells $\left(1 \times 10^{6}\right)$ pre-incubated in the absence (control) (white column) or presence (black columns) of different concentrations of EGF for $24 \mathrm{~h}$ were placed into each chamber well and cultured for $3 \mathrm{~h}$. The cells that reached the bottom surface of the membrane were stained with hematoxylin and the numbers of cells were counted. Regression analysis indicated a significant positive relationship between the EGF concentration and the number of migrating cells. Statistically significant differences are indicated by asterisks $(* *, \mathrm{P}<0.01)$.

$\mathrm{B}, \mathrm{BeWo}$ cells were pre-incubated with (right columns) or without (left columns) $10 \mathrm{nM}$ human EGF for $24 \mathrm{~h}$ in the presence of the same anti- $\alpha 2$ integrin antibody described in the legend for Fig. 4 (black columns), control mouse IgG1 (white columns), or anti- $\alpha 1$ integrin antibody (shaded columns). The antibody or control IgG1 was added to the cells immediately after the cells were plated in the Boyden chambers. Results are expressed as the number of migrating cells. Data are shown as the mean \pm S.D. $(n=5)$. Two-way ANOVA was used to assess whether there were significant differences in the number of migrating cells within the same EGF concentration among each antibody treatment. Statistically significant differences are indicated by asterisks (**, $\mathrm{P}<0.01)$. 
between keratinocytes, suggesting its participation in cell-cell adhesion [35]. $\alpha 2$ integrin also plays an important role in cell migration and in the reorganization of the collagenous matrix of fibroblasts [36] and osteogenic cells [37]. In the present study we demonstrated a positive effect of EGF on $\alpha 2$ integrin expression in human BeWo choriocarcinoma cells. Previous reports indicated that EGF increases the level of $\alpha 2$ integrin expression in various cells such as squamous carcinoma cells [38] and a colon carcinoma cell line [39]. Furthermore, EGF was shown to induce cell migration activity via upregulation of $\alpha 2$ integrin in gastric cancer cells [26]. However, little information is available about how EGF regulates $\alpha 2$ integrin expression and affects the invasive activity of trophoblast cells. Therefore, our findings should provide new insights into the possible functions of $\alpha 2$ integrin in human trophoblast cells.

EGF increased the cell surface expression of $\alpha 2$ integrin alone among several $\alpha$ subunits in BeWo cells. These results are consistent with reports showing that EGF upregulated the expression of $\alpha 2$ integrin but not that of $\alpha 3$ or $\alpha 5$ integrins in human squamous carcinoma cells [40]. Moreover, it is notable that the responses of $\alpha 2$ and $\beta 1$ integrins to EGF were different. Other studies have also demonstrated such differences between the responses of these two integrins. For example, increased surface expression of $\alpha 2 \beta 1$ integrin was reported to be a consequence of increased steadystate levels of $\alpha 2$ integrin, while $\beta 1$ mRNA was not altered during megakaryocytic differentiation [40]. Glucocorticoid suppressed $\alpha 2$ integrin expression markedly in the CTB, but had a weaker effect on $\beta 1$ integrin [41]. In addition, EGF did not stimulate the biosynthesis of $\beta 1$ integrin in 3T3-L1 cells [42]. These data suggest the possibility that $\alpha 2 \beta 1$ integrin expression is mainly affected by the regulation of $\alpha 2$ integrin, and that signaling events specific for individual integrin heterodimers are triggered by the $\alpha$ subunit.

The expression of $\alpha 2$ integrin was enhanced by EGF at the level of mRNA expression. The analysis of the 5'-flanking region of the $\alpha 2$ integrin gene revealed that several transcription factor binding sites, including AP-1, Sp1 and nuclear factor- $\kappa \mathrm{B}(\mathrm{NF}-\kappa \mathrm{B})$ sites, are present in the promoter region [43], and in fact the regulation of $\alpha 2$ integrin has been shown to involve NF- $\mathrm{kB}$ [44]. Furthermore, EGF has been shown to induce NF- $\mathrm{KB}$ in breast cancer cell lines
[45] and A431 carcinoma cells [34]. Both $\alpha 2$ and $\beta 1$ integrin promoters contain $\mathrm{AP}-1$ and $\mathrm{Sp} 1$ sites. Therefore, NF- $\mathrm{KB}$ is a potential candidate for the mediator of EGF induction of $\alpha 2$ integrin mRNA by EGF.

By culturing mouse embryos in culture vessels coated with ECM proteins, it was shown that at least three alpha integrins $(\alpha 2, \alpha 6$, and $\alpha 7)$ are expressed when embryos attach to the matrix [46]. With regard to EGF action, direct effects of EGF and transforming growth factor alpha (TGF- $\alpha$ ) on trophoblast outgrowth of the mouse blastocyst in vitro was demonstrated [20]. Based on these facts, we hypothesized that $\alpha 2$ integrin plays a significant role during the initial stage of trophoblast invasion into the endometrium. We have provided several lines of evidence here that an increase of $\alpha 2$ integrin is involved in the EGF-induced invasiveness and chemokinesis of BeWo cells. In normal human pregnancy, the invasion of the uterus by the CTB is accompanied by marked changes in the expression of cell adhesion molecules [47]. There have been previous reports showing that $\alpha 1$ or $\alpha 5$ integrins are involved in the invasive activity of the trophoblast cells [48]. However, it was hitherto unknown whether $\alpha 2$ integrin affects the invasiveness of these cells. Therefore, it is noteworthy that we have identified $\alpha 2$ integrin as an important player in the invasive activity of BeWo cells. EGF and the EGF receptor are expressed by normal placental trophoblast cells from as early as the fourth to fifth week of gestation, and their expression then continues until term [49]. Thus, EGF may be a key factor in the biological function of the trophoblast via the regulation of $\alpha 2 \beta 1$ integrin expression throughout pregnancy. The fact that $\alpha 2$ integrin is involved in growth factor-mediated cell invasion gives us new insights into the biology of the trophoblast. Because both human placental cells and choriocarcinoma cells contain EGF receptors, ligand (s) for the EGF receptor, such as EGF, TGF- $\alpha$, and heparin-binding EGF, may play important roles in normal as well as abnormal placental cell growth and differentiation [47].

Invasion through the uterine epithelium is presumably promoted by proteases on the trophoblast cell surface. Integrins facilitate invasion by recruiting ECM-degrading proteinases such as matrix metalloproteinases (MMPs) [50]. Recent studies have revealed that two collagen receptors, $\alpha 1 \beta 1$ and $\alpha 2 \beta 1$ integrins, regulate distinct functions in cells, although 
both integrins are expressed by many cell types. $\alpha 2 \beta 1$ integrin mediates activation of p38 mitogen-activated protein kinase (p38MAPK) [51] and regulates MMP-1 and MMP-13 [52], whereas $\alpha 1 \beta 1$ integrin activates the Ras-extracellular signal-related kinase (Ras-ERK) signal transduction pathway [53, 54]. The distinct functions of individual $\alpha$-subunits sharing a common $\beta 1$-integrin may be due to their activation of different signaling processes. Further studies of the $\alpha 2 \beta 1$ integrin signaling cascade will lead to a better understanding of the biological activity of trophoblast cells.

\section{Acknowledgments}

The authors thank Dr. Kensuke Miyake (Institute of Medical Science, University of Tokyo) for providing anti- $\alpha 4,-\alpha 5$ and $-\beta 1$ integrin antibodies, Dr. Dai Imamura (Nippon Organon K.K.) for valuable assistance with the statistical analysis, Dr. Masahiro Sakata and Dr. Elizabeth Nakajima for critical reading of the manuscript, and Ms. Ayako Okamura and Ms. Tomoko Iwaki for technical and secretarial assistance.

\section{References}

1. Strickland S, Richards WG (1992) Invasion of the trophoblasts. Cell 71: 355-357.

2. Vicovac L, Jones CJ, Aplin JD (1995) Trophoblast differentiation during formation of anchoring villi in a model of the early human placenta in vitro. Placenta 16: 41-56.

3. Cross JC, Werb Z, Fisher SJ (1994) Implantation and the placenta: key pieces of the development puzzle. Science 266: 1508-1518.

4. Roberts RM, Farin CE, Cross JC (1990) Trophoblast proteins and maternal recognition of pregnancy. Oxf Rev Reprod Biol 112: 147-180.

5. Zhou Y, Fisher SJ, Janatpour M, Genbacev O, Dejana E, Wheelock M, Damsky CH (1997) Human cytotrophoblasts adopt a vascular phenotype as they differentiate. A strategy for successful endovascular invasion? J Clin Invest 99: 2139-2151.

6. Coutifaris C, Omigbodun A, Coukos G (1998) Integrins, endometrial maturation, \& human embryo implantation. Semin Reprod Endocrinol 16: 219-229.

7. Morrish DW, Dakour J, Li H (1998) Functional regulation of human trophoblast differentiation. J Reprod Immunol 39: 179-195.

8. Marshall JF, Rutherford DC, McCartney AC, Mitjans F, Goodman SL, Hart IR (1995) $\alpha v \beta 1$ is a receptor for vitronectin and fibrinogen, and acts with $\alpha 5 \beta 1$ to mediate spreading on fibronectin. J Cell Sci 108: 1227 1238.

9. Sobel RA, Hinojoza JR, Maeda A, Chen M (1998) Endothelial cell integrin laminin receptor expression in multiple sclerosis lesions. Am J Pathol 153: 405-415.

10. Sutherland AE, Calarco PG, Damsky CH (1993) Developmental regulation of integrin expression at the time of implantation in the mouse embryo. Development 119: 1175-1186.

11. Aplin JD (1997) Adhesion molecules in implantation. Rev Reprod 2: 84-93.

12. Bowen JA, Hunt JS (1999) Expression of cell adhesion molecules in murine placentas and a placental cell line. Biol Reprod 60: 428-434.

13. Damsky $\mathrm{CH}$, Librach $\mathrm{C}$, Lim $\mathrm{KH}$, Fitzgerald $\mathrm{ML}$, McMaster MT, Janatpour M, Zhou Y, Logan SK, Fisher SJ (1994) Integrin switching regulates normal trophoblast invasion. Development 120: 3657-3666.

14. Burger SR, Zutter MM, Sturgill-Koszycki S, Santoro SA (1992) Induced cell surface expression of functional $\alpha 2 \beta 1$ integrin during megakaryocytic differentiation of K562 leukemic cells. Exp Cell Res 202: 28-35.

15. Hewish MJ, Takada Y, Coulson BS (2000) Integrins $\alpha 2 \beta 1$ and $\alpha 4 \beta 1$ can mediate SA11 rotavirus attachment and entry into cells. $J$ Virol 74: 228-236.

16. Imai $\mathrm{T}$, Kurachi $\mathrm{H}$, Adachi $\mathrm{K}$, Adachi H, Yoshimoto $\mathrm{Y}$, Homma H, Tadokoro C, Takeda S, Yamaguchi M, Sakata M (1995) Changes in epidermal growth factor receptor and the levels of its ligands during menstrual cycle in human endometrium. Biol Reprod 52: 928938.

17. Hofmann GE, Drews MR, Scott RT Jr, Navot D, Heller D, Deligdisch L (1992) Epidermal growth factor and its receptor in human implantation trophoblast: immunohistochemical evidence for autocrine/paracrine function. J Clin Endocrinol Metab 74: 981-988.

18. Evain-Brion D, Alsat E (1994) Epidermal growth factor receptor and human fetoplacental development. $J$ Pediatr Endocrinol 7: 295-302.

19. Filla MS, Kaul KL (1997) Relative expression of epidermal growth factor receptor in placental cytotrophoblasts and choriocarcinoma cell lines. Placenta 18: 17-27.

20. Machida T, Taga M, Minaguchi H (1995) Effects of epidermal growth factor and transforming growth factor alpha on the mouse trophoblast outgrowth in vitro. Eur J Endocrinol 133: 741-746.

21. Harvey MB, Leco KJ, Arcellana-Panlilio MY, Zhang X, Edwards DR, Schultz GA (1995) Proteinase expression in early mouse embryos is regulated by leukaemia 
inhibitory factor and epidermal growth factor. Development 121: 1005-1014.

22. Li RH, Zhuang LZ (1997) The effects of growth factors on human normal placental cytotrophoblast cell proliferation. Hum Reprod 12: 830-834.

23. Ilekis J, Benveniste R (1985) Effects of epidermal growth factor, phorbol myristate acetate, and arachidonic acid on choriogonadotropin secretion by cultured human choriocarcinoma cells. Endocrinology 116: 2400-2409.

24. Lim KH, Zhou Y, Janatpour M, McMaster M, Bass K, Chun SH, Fisher SJ (1997) Human cytotrophoblast differentiation/invasion is abnormal in pre-eclampsia. Am J Pathol 151: 1809-1818.

25. Hirano $T$, Higuchi $T$, Katsuragawa $H$, Inoue $T$, Kataoka N, Park KR, Ueda M, Maeda M, Fujiwara H, Fujii S (1999) CD9 is involved in invasion of human trophoblast-like choriocarcinoma cell line, BeWo cells. Mol Hum Reprod 5: 168-174.

26. Murakami N, Fukuchi S, Takeuchi K, Hori T, Shibamoto S, Ito F (1998) Antagonistic regulation of cell migration by epidermal growth factor and glucocorticoid in human gastric carcinoma cells. J Cell Physiol 176: 127-137.

27. Aplin JD, Sattar A, Mould AP (1992) Variant choriocarcinoma (BeWo) cells that differ in adhesion and migration on fibronectin display conserved patterns of integrin expression. $J$ Cell Sci 103: 435-444.

28. Irving JA, Lala PK (1995) Functional role of cell surface integrins on human trophoblast cell migration: regulation by TGF-beta, IGF-II, and IGFBP-1. Exp Cell Res 217: 419-427.

29. Nomura S, Goto S, Ino K, Nakanishi T, Okamoto T, Mano H, Kurauchi O, Mizutani S, Tomoda Y (1996) Autocrine mechanism of epidermal growth factor in choriocarcinoma cell proliferation. Mol Cell Endocrinol 124: 63-69.

30. Cao H, Lei ZM, Bian L, Rao CV (1995) Functional nuclear epidermal growth factor receptors in human choriocarcinoma JEG-3 cells and normal human placenta. Endocrinology 136: 3163-3172.

31. Nachtigall MJ, Kliman HJ, Feinberg RF, Olive DL, Engin O, Arici A (1996) The effect of leukemia inhibitory factor (LIF) on trophoblast differentiation: a potential role in human implantation. J Clin Endocrinol Metab 81: 801-806.

32. Ando N, Hirahara F, Fukushima J, Kawamoto S, Okuda K, Funabashi T, Gorai I, Minaguchi H (1998) Differential gene expression of TGF- $\beta$ isoforms and TGF- $\beta$ receptors during the first trimester of pregnancy at the human maternal-fetal interface. Am J Reprod Immunol 40: 48-56.

33. LaFlamme SE, Homan SM, Bodeau AL, Mastrangelo AM (1997) Integrin cytoplasmic domains as connectors to the cell's signal transduction apparatus. Matrix
Biol 16: 153-163.

34. Maemura M, Iino $Y$, Horiguchi J, Takei H, Horii $Y$, Koibuchi Y, Yokoe T, Takeyoshi I, Ohwada S, Morishita Y (1999) Effects of interferon-alpha on cellular proliferation and adhesion of breast carcinoma cells. Oncol Rep 6: 557-561.

35. Larjava H, Peltonen J, Akiyama SK, Yamada SS, Gralnick HR, Uitto J, Yamada KM (1990) Novel function for $\beta 1$ integrin in keratinocyte cell-cell interactions. J Cell Biol 110: 803-815.

36. Klein CE, Dressel D, Steinmayer T, Mauch C, Eckes B, Krieg T, Bankert RB, Weber L (1991) Integrin $\alpha 2 \beta 1$ is upregulated in fibroblasts and highly aggressive melanoma cells in three-dimensional collagen lattices and mediates the reorganization of collagen I fibrils. J Cell Biol 115: 1427-1436.

37. Riikonen T, Koivisto L, Vihinen P, Heino J (1995a) Transforming growth factor- $\beta$ regulates collagen gel contraction by increasing $\alpha 2 \beta 1$ integrin expression in osteogenic cells. J Biol Chem 270: 376-382.

38. Fujii K, Dousaka-Nakajima N, Imamura S (1995) Epidermal growth factor enhancement of HSC-1 human cutaneous squamous carcinoma cell adhesion and migration on type I collagen involves selective upregulation of $\alpha 2 \beta 1$ integrin expression. Exp Cell Res 216: 261-272.

39. Solic N, Davies DE (1997) Differential effects of EGF and amphiregulin on adhesion molecule expression and migration of colon carcinoma cells. Exp Cell Res 234: 465-476.

40. Zutter MM, Fong AM, Krigman HR, Santoro SA (1992) Differential regulation of the $\alpha 2 \beta 1$ and $\alpha \operatorname{IIb} \beta 3$ integrin genes during megakaryocytic differentiation of pluripotential K562 cells. J Biol Chem 267: 2023320238.

41. Ryu JS, Majeska RJ, Ma Y, LaChapelle L, Guller S (1999) Steroid regulation of human placental integrins: suppression of $\alpha 2$ integrin expression in cytotrophoblasts by glucocorticoids. Endocrinology 140: 39043908.

42. Ignotz RA, Massague J (1987) Cell adhesion protein receptors as targets for transforming growth factor-beta action. Cell 51: 189-197.

43. Zutter MM, Santoro SA, Painter AS, Tsung YL, Gafford A (1994) The human $\alpha 2$ integrin gene promoter. Identification of positive and negative regulatory elements important for cell-type and developmentally restricted gene expression. J Biol Chem 269: 463-469.

44. Nissinen L, Westermarck J, Koivisto L, Kahari VM, Heino J (1998) Transcription of $\alpha 2$ integrin gene in osteosarcoma cells is enhanced by tumor promoters. Exp Cell Res 243: 1-10.

45. Biswas DK, Cruz AP, Gansberger E, Pardee AB (2000) Epidermal growth factor-induced nuclear factor $\mathrm{\kappa B}$ activation: A major pathway of cell-cycle progression 
in estrogen-receptor negative breast cancer cells. Proc Natl Acad Sci USA 97: 8542-8547.

46. Sutherland AE, Calarco PG, Damsky CH (1988) Expression and function of cell surface extracellular matrix receptors in mouse blastocyst attachment and outgrowth. J Cell Biol 106: 1331-1348.

47. Zhou Y, Damsky CH, Chiu K, Roberts JM, Fisher SJ (1993) Preeclampsia is associated with abnormal expression of adhesion molecules by invasive cytotrophoblasts. J Clin Invest 91: 950-960.

48. Kilburn BA, Wang J, Duniec-Dmuchowski ZM, Leach RE, Romero R, Armant DR, Duniec-Dmuchkowski ZM (2000) Extracellular matrix composition and hypoxia regulate the expression of HLA-G and integrins in a human trophoblast cell line. Biol Reprod 62: 739-747.

49. Lennard SN, Gerstenberg C, Allen WR, Stewart F (1998) Expression of epidermal growth factor and its receptor in equine placental tissues. $J$ Reprod Fertil 112: 49-57.

50. Brooks PC, Stromblad S, Sanders LC, von Schalscha TL, Aimes RT, Stetler-Stevenson WG, Quigley JP,
Cheresh DA (1996) Localization of matrix metalloproteinase MMP-2 to the surface of invasive cells by interaction with integrin $\alpha v \beta 3$. Cell 85: 683-693.

51. Ivaska J, Reunanen H, Westermarck J, Koivisto L, Kahari VM, Heino J (1990) Integrin $\alpha 2 \beta 1$ mediates isoform-specific activation of p38 and upregulation of collagen gene transcription by a mechanism involving the $\alpha 2$ cytoplasmic tail. J Cell Biol 147: 401-416.

52. Riikonen T, Westermarck J, Koivisto L, Broberg A, Kahari VM, Heino J (1995b) Integrin $\alpha 2 \beta 1$ is a positive regulator of collagenase (MMP-1) and collagen a1(I) gene expression. J Biol Chem 270: 13548-52.

53. Mainiero F, Murgia C, Wary KK, Curatola AM, Pepe A, Blumemberg M, Westwick JK, Der CJ, Giancotti FG (1997) The coupling of $\alpha 6 \beta 4$ integrin to Ras-MAP kinase pathways mediated by Shc controls keratinocyte proliferation. EMBO J 16: 2365-2375.

54. Pozzi A, Wary KK, Giancotti FG, Gardner HA (1998) Integrin $\alpha 1 \beta 1$ mediates a unique collagen-dependent proliferation pathway in vivo. J Cell Biol 142: 587594. 